\title{
ТОЛЕРАНТНІСТЬ ЗМІ В УМОВАХ КРИЗОВИХ СИТУАЦЙ
}

\author{
Тетяна Хоменко \\ Львівський національний університет імені Івана Франка, \\ вул. Генерала Чупринки, 49, 79044, Львів, Україна, \\ e-mail: homenko.tet@gmail.com \\ https://orcid.org/0000-0003-2917-3469
}

У статті йдеться про деякі проблеми, з якими зіштовхуються журналісти, коли доводиться висвітлювати непрості конфліктні та кризові періоди в житті людини, країни, суспільства загалом. Зокрема, автор бере до уваги той факт, що кризи - це своєрідне входження в смугу загострення конфлікту, а, отже, журналіст як медіатор суспільного полілогу має надавати спільноті інформацію так би мовити на випередження, 3 метою уникнення конфлікту або ж вирішення його на різних рівнях (політичному, економічному, соціокультурному, особистісному) суспільного життя через якісний аналіз і оцінку конфліктної ситуації.

Ключові слова: медіа, діалог, криза, конфлікт, журналістська етика.

Постановка проблеми. Передовсім актуальність обраної теми варто окреслити кількома параметрами. По-перше, упродовж життя ми стикаємося з різноманітними кризовими явищами і на особистісному рівні, i на рівні налагодження діалогу 3 іншими. Окрім того, не оминають нас і кризи економічні, політичні, демографічні, в культурному житті, кризи суспільні, а також різноманітні надзвичайні ситуації. Але треба пам'ятати, що криза - це входження в смугу загострення конфлікту, особливо це стосується комунікативних потоків, в яких чи не першочергову роль виконують 3МI, які й самі можуть спричинити конфлікт чи опинитися в ньому. ЗМI - це частина реалій нашого життя, а їхня діяльність має бути конструктивною, оскільки, і це - по-друге, часто для виходу з кризової ситуації, правильного іï аналізу та оцінки потрібен медіатор. У контексті нашої теми таким медіатором можуть і навіть мають бути засоби масової інформації, які створюють толерантний інформаційний простір, в якому кожна подія висвітлюється через призму грунтовного аналізу, фахових коментарів, а не лише стає доповненням новинної стрічки подій. Дозвільний споживач інформації сьогодні, з одного боку - має доступ до найрізноманітніших медійних джерел, а з іншого - ризикує розгубитися і загубитися не лише в тематичному розмаїтті, але й в плюралістичному потоці правд, напівправд і відвертого маніпулювання свідомістю. По-третє, саме коли йдеться про стандарти журналістської діяльності, доводиться констатувати той факт, що найчастіше і редакційні колективи, і самі журналісти, якщо говорити про обов’язок відповідальності працівників медіа, керу-

(C) Хоменко Т., 2019 
ються здебільшого кантівським «моральним законом у собі», чого інколи замало, бо i йому також можна надати маніпулятивного звучання. Тож деонтологічна проблема свободи вільного вибору за таких умов набуває особливого звучання: толерантний вибір журналіста має бути на боці правди, це по-перше, а по-друге, вибір професійного журналіста має спиратися на поняття колективного добра, без корисливого трактування такого вчинку. Звісно, у цьому вагомою підтримкою будь-кого з журналістів могли би бути виписані редакційні кодекси, проте цей вид регламентації роботи журналіста, на жаль, не набув популярності.

Зате останнім часом, особливо впродовж 2014-2016 pp., журналісти самі, і це позитивний факт, з особливою увагою переглядають стандарти журналістської діяльності, діляться досвідом на медіафорумах, семінарах, тренінгах та майстер-класах.

Огляд літератури. Також варто зауважити, що висвітлення позиції журналіста у кризових/конфліктних ситуаціях, дотримання професійних стандартів у динамічній системі інформаційного забезпечення різних сфер суспільного життя досліджували і досліджують у різних ракурсах українські і закордонні науковці, зокрема О. Голуб [1], М. Житарюк [2], І. Земляна [3], М. Зубарєва [4], Дж. Лалл [5], Й. Лось [6], I. Михайлин [7], Г. Почепцов [8], В. Різун [9], О. Чапала [10] та ін.

Невирішені раніше проблеми. Сьогодні нагальною $є$ потреба об'єднати зусилля практикуючих журналістів, медіаекспертів, науковців, журналістикознавців для вироблення інформаційної, аналітичної, пропагандистської та деонтологічної стратегії діяльності ЗМІ у конфліктно-кризових ситуаціях.

Мета статті - розглянути межі толерантностей ЗМІ в конфліктно-кризових ситуаціях і те, як самі журналісти визначають для себе професійний стандарт у деонтологічному зрізі цього поняття.

Основний виклад. Чи не найбільша кількість досліджень, пов'язаних з висвітленням ролі ЗМІ, поведінки журналістів у кризових ситуаціях з'явилась протягом 2014-2016 рр. Звісно, це було зумовлено неабиякою увагою світової та української аудиторії до подій в Україні. Відповідні інституції, групи журналістів, медіаексперти оприлюднили протягом цього часу кілька досліджень, які заслуговують на увагу і дотичні до теми нашого дослідження, оскільки також порушують між іншим питання етичного й деонтологічного характеру. Щоправда, варто зауважити, що й самі дослідження і журналісти, які були залучені до них, і незалежні медіаексперти, і так би мовити сторонні спостерігачі інколи в поняття «кризова ситуація» вкладали різний зміст.

«Україна живе в перманентній кризі, яка ризикує прийняти катастрофічний характер, якщо в ситуацію не втрутяться об'єктивні ЗМІ», - написав в 2016 році німецький політолог О. Вайнберг [11]. Саме він слушно зауважив і той факт, що дуже часто різні кризи підсилюють одна одну і розглянув одну з них саме як конфлікт. Зокрема, йдеться про конфлікт, що загальмував процес створення суспільного телебачення i спричинив кризову ситуацію у сфері громадського мовлення. В подальшому дослідженні О. Вайнберг слушно зауважив, що саме розмови про кризу перетворюють її на повсякденність. Тобто, «чим більше ми чуємо це слово, тим більше ми звикаємо до нього. Але чи ми звикаємо до слова “криза”, чи звикаємо до самого явища, чим би воно насправді не було? Незважаючи на те, що розмови про кризи зазвичай містять невизначеність, такі розмови також містять заклик до дій. Кризи роблять дійовихосіб здатними змінювати політичні, економічні або соціальні системи у способи, 
що раніше вважались неможливими. Звичайно, перш за все можна поставити питання, як з'явилась сучасна версія терміну. В контексті нинішніх подій в Україні, очевидно, що поштовхом стала відмова тодішньої влади від Угоди про асоціацію з Свропою наприкінці 2013 року. Вона призвела до протестів, насильства з боку режиму, анексії Криму та військового конфлікту на сході України». Ці міркування політолога зрештою пояснюють і той масив наукових і журналістських досліджень, спрямованих на з'ясування ролі, місця і толерантностей ЗМІ у кризових/конфліктних ситуаціях. Саме потреба протидіяти російській агресії змусила журналістів і журналістикознавців переглянути баланс пропагандистських смислів, інформаційних посилів і визначитись 3 вартісними пріоритетами у висвітленні тих конфліктно-кризових явищ, які становлять сьогодні предмет дослідження і обговорення.

Тема висвітлення у засобах масової інформації кризових явищ сьогодні набуває особливого звучання, а відтак і численних досліджень, завдяки яким, власне, в науковому, і не лише, обігу з'являються нові терміни, на кшталт «кризові комунікації» [12], «антикризові комунікації» [13], «мова ворожнечі», «конфліктно вразливі групи» [14], «гуманітарні комунікації» [15]. Така інформаційно-мовна парадигма сьогодні притаманна і журналістським матеріалам і, відповідно, журналістикознавчим дослідженням. Окрім того, вочевидь, вона є частиною нових форм подачі пропагандистських матеріалів, які набирають нових інформаційно-лексичних форм і свідченням того, що в інформаційному просторі, з огляду на події на Сході України і в Криму, також відбулась своєрідна криза пропаганди, яка, на думку Г. Почепцова, «вийшовши з моди, отримала безліч інших назв, щоб не називатися пропагандою. Це довгий список: інформаційна війна, психологічна війна, м'яка сила, стратегічна комунікація, ідеологічна війна, війна ідей, операції впливу, публічна дипломатія... Причому цікаво, що ідеологічна війна, війна ідей, операції впливу з'явилися як наслідок настання довгої війни, коли виявився затребуваним досвід війни холодної. Тобто відбулося певне повернення до минулого» [16].

Г. Почепцов, розмірковуючи про завдання комунікантів у ситуації отримання, надання і сприймання інформації, наголошує на ролі ЗМІ як вагомого комунікатора і вказує на те, що завданням комунікатора є інтерпретація ситуації в потрібному ракурсі. Водночас він вказує, що інформаційне поле «зазнає суттєвих трансформацій, коли стикається з полем реальностей» $[8,17]$. На шляху перетворення реальної події до інформації, а згодом - інформації до реалій життя, часто відбувається підміна фактів і коментарів. Особливо чітко виявляється це сьогодні, коли йдеться про пропагандистські інформаційні посили РФ, які російська аудиторія сприймає як істину в останній інстанції, не вдається до критичного осмислення та аналізу інформації, не оцінює інформацію як таку, реалії їі створення і мету призначення - коли інформація є вторинною, а коли мета її побутування в реаліях життя первинна. Це чи не найпевніший крок до когнітивного дисонансу та кризи світосприйняття, а відтак, $\mathrm{i}$ до викривлення приватного поля інформаційного співвідношення реального і накинутого віртуозним інфотворенням реального.

Динаміка формування інформаційних потоків сьогодні почасти деструктивно впливає на формування цілісної і об'єктивної інформаційної візії у конкретної аудиторії. Тут варто пам'ятати, що бути поінформованою бажає аудиторія різного віку. Особливо сьогодні, в контексті кризи нерозуміння між старим і новим, тобто між поколінням радянських часів, старшим поколінням, яке має досвід переживан- 
ня імперії Слова часів Радянського Союзу (Г. Почепцов), коли ЗМІ призводили до конфлікту між вербальною та візуальною інтерпретацією (а візуальну інформацію масова свідомість завжди сприймала як найбільш правдиву) $[8,18]$, і поколінням нового мислення, нових інформаційних можливостей, свободи довільного, часто надто вільного, інтерпретування будь-якої інформації. Ця молодіжна аудиторія, власне, і $\epsilon$ тим контингентом, який також добре орієнтується в нових реаліях через ширші можливості доступу до медіаконтенту, через ширше коло спілкування, завдяки соціальним мережам, можливостям навчатися за кордоном, подорожувати, але водночас це ті, хто (власне на хвилі ширших можливостей) не завжди враховує попередній інформаційний контекст, тобто своєрідні «уроки минулого».

Питання правильного і помилкового (неправильного), позитивного і негативного - це також ті дихотомічні пари, які сьогодні зазнають смислової кризи. Сьогодні постаємо перед проблемою вибору в інформаційному полі, і цей вибір - дражливе питання для багатьох, оскільки множинність комунікативних векторів і кризові потрясіння можуть у підсумку сприяти викривленню реальності, розгубленості аудиторії, яка намагається відшукати істинний смисл серед натяків, підтекстів, фейків і тролінгу. ЗМІ повинні враховувати проблемність вибору споживача інформації, аби уникати конфліктів, запобігати їм, знаходити шляхи виходу з конфліктних ситуацій (особистісні вони чи суспільні), які своєю чергою призводять до ситуацій кризових (або криз): з одного боку, відповідно, моральних, духовних, гендерних, психологічних, а з іншого, коли говоримо про кризові суспільні ситуації, то це - економічні, політичні, соціокультурні, мілітарні, медійні, та на релігійній основі.

Варто згадати й про структурні кризи, до яких можуть призводити, зокрема, міжнаціональні, міжкультурні, міжконфесійні конфлікти, кризовість виборчого процесу та ін.

Широка аудиторія споживачів інформації не завжди спроможна оцінити складність роботи медіапрацівників та й загалом ЗМІ в умовах постійного вибору якнайкращих шляхів фахового аналізу, коментування та оцінювання усіх цих процесів, А отже чи не найважливіше завдання ЗМІ - запобігати загостренню будь-якого конфлікту й уникати конфлікту інтересів (і не лише внутрішньомедійного, але й такого, який, вийшовши за межі редакції, провокує недовіру до засобу масової інформації та його працівників).

Все це відображається в площині конфліктних ситуацій, які потребують постійного, тобто перманентного толерантного діалогу сторін, що вступили у фазу суперечностей, які можна подолати лише через діалог. Адже суперечності зазвичай структурно складні, багатоступеневі, вирішення одних часто провокує смислове зіткнення інших, навіть суперечливих, протилежних поглядів, діалогічне примирення яких може призвести до структурної цілості, але в плюралістичному зіткненні різних поглядів однаково не веде до остаточної перемоги одного з них. Тобто, з одного боку, ЗМІ сприяють діалогізації процесу виходу з кризи, мінімізують протиріччя, а з іншого, розставляючи всі крапки над «і», остаточний висновок залишають за аудиторією. І в цьому комунікативному процесі діалог можна прирівняти до постійного розвитку у прагненні віднайти істину. Потреби, очікування, зацікавлення аудиторії piзні. Як різна й аудиторія: одна, пасивна, яка живе за принципом «моя хата скраю», інша - активна, небайдужа до долі країни і водночас хоче бути почутою. Отже, ЗМІ, щоб залишатися в процесі плідного діалогу, потрібно вміти слухати, бо, як пише го- 
ловний редактор часопису «Guardian» Кетрін Вінер: «У бурхливу епоху ЗМІ повинні визначити свої цінності та принципи. У той момент, коли люди втрачають віру в свою здатність брати участь у політиці і в те, що будуть почутими, засоби масової інформації можуть відігравати важливу роль... Якщо журналісти стають далекими від життя інших людей, вони пропускають історію, і люди не довіряють їм» [17]. Тож діалогізація інформаційного простору, як умова формування довірливого обміну якісним і конструктивним контентом, є тією цінністю, яка підсилює довіру до 3MI, збагачує порядок денний журналістики загалом, змінює шаблони мислення, стимулює громадянську активність. Медіа як елемент громадянського суспільства формують публічний масовий дискурс і тому зобов’язані підтримувати суспільний діалог на принципах толерантності.

Українські журналісти розуміють свою роль у висвітленні кризово-конфліктних ситуацій, особливо сьогодні. Скажімо, предметом дослідження «Спеціального звіту» [18], в якому йдеться про висвітлення конфлікту на Сході України в українських медіа, є цінності, установки і журналістські практики, поширені в редакціях. Звіт підготувала ГО «Детектор медіа» в рамках проекту, що здійснювався у партнерстві 3 Офісом Координатора проектів ОБСС в Україні за фінансової підтримки Посольства Великобританії в Україні. Керівник дослідницької групи Д. Орлова зазначила, що у дослідженні взяли участь журналісти і редактори , які безпосередньо висвітлювали теми, пов'язані з конфліктом. Передовсім дослідницька група наголосила на вкрай важливих у цій ситуації аспектах:

- плюралізм у підходах до висвітлення конфлікту та відсутність універсальних правил;

- відсутність прописаних редакційних практик (щоправда, це стосується й висвітлення інших тем), через що саме професійні стандарти, а не політика редакцій стають предметом інтерпретації журналістів, які змушені спиратися на «власний досвід та знання, а не на редакційні настанови» $[18,3]$.

Зауважено було й психологічну проблему, з якою стикаються журналісти: складність об'єктивного висвітлення через перебування над ситуацією, через відчуття співпричетності, і відчуття непевності щодо можливості дотримання стандартів без шкоди для країни.

Серед психологічних чинників висвітлення конфлікту слушно названо було й емпатію, яка виникає в процесі спілкування з військовими, волонтерами і є позитивом у діалозі, скерованому на аудиторію. Водночас проблемою залишається той факт, що у фокус уваги рідше потрапляє інша сторона конфлікту: лояльні і нелояльні до української влади, до уряду, які гірше йдуть на контакт; ті, хто постраждав чи мав причетність до конфлікту, тобто «конфліктно вразливі групи населення», як про це зазначає Інститут масової інформації в порадах для журналістів [14]. Але водночас це та група населення, яка не діалогізує із суспільством або відчуває брак суспільної уваги до себе. Цю проблему дослідницька група «Детектор медіа» пояснює так: «Брак теми діалогу в медіа пов'язаний із відсутністю чітко артикульова-ної державної політики щодо майбутнього окупованих територій та мешканців цих територій. За таких умов більшість журналістів не готові брати на себе відповідальність за просування ідеї діалогу, хоча готові такий діалог висвітлювати» $[18,19]$.

Але суб'єктивно побачити ситуацію і об'єктивно їі висвітлити - робота відповідальна. Неупереджено аналізувати всі факти, щоб не спричинити загострення 
конфлікту і переростання його у фазу кризовості чи навіть катастрофічності, а допомогти вирішити його - також потребує неабиякої мобілізації інтелектуальних, емоційних, моральних зусиль, щоб, з іншого боку, ані журналіст, ані ЗМІ самі не опинилися в центрі конфлікту. Це питання неодноразово порушували також автори проекту «Конфлікт у медіа і медіа в конфлікті: донесення дражливих питань через засоби масової інформації» [19], маючи на меті показати, що українське суспільство спроможне вирішувати конфлікти, завдяки якісному їх висвітленню у засобах масової інформації і залученню широкої аудиторії до розбудови толерантного загальнонаціонального діалогу.

Висновки. 3 усього сказаного випливає, що толерантність ЗМІ в умовах кризових ситуацій - це так би мовити цілий комплекс толерантностей, а саме: толерантне ставлення до споживачів інформації; толерантність надавача інформації, толерантне ставлення до нього і толерантне використання цієї інформації, толерантне використання ексклюзивної інформації, а також неупереджені визначення причин і рівнів кризовості у суспільстві та діалогічне їх вирішення. Журналістика сьогодні має бути живим, чутливим організмом, який функціонує не понад ситуацією, а в 110 глибинах, переживає ту саму стурбованість перед кризами, що й кожен з реципієнтів. Обов'язок відповідальності сьогодні справді є тим вартісним компонентом, який робить вартісною і роботу медійників. Щоденне обговорення будь-яких конфліктно кризових ситуацій без аргументованого обміну думками - це популізм. Бути над ситуацією із розумінням цієї ситуації - почасти краще, ніж залишатись нібито нейтральним. I те, що сьогодні журналісти відкрито про це говорять, свідчить про їхній професіоналізм і розуміння місійності свого призначення.

\section{REFERENCES}

1. Голуб О. Медіакомпас: путівник професійного журналіста. Практ. посібник / Iнститут масової інформації / О. Голуб. К. : ТОВ «Софія-А», 2016. 184 с.

2. Житарюк М. Теорії та моделі масової інформації (Масова комунікація): навч.-метод. посібник / М. Житарюк. Львів : ЛНУ імені Франка, 2008. 244 с.

3. Земляна I. Журналіст і (HE) безпека. Посібник для журналістів, які працюють в небезпечних умовах / Інститут масової інформації / I. Земляна. Київ: Інститут масової інформації, 2016. 194 с.

4. Зубарєва М. Робота з ЗМІ в кризових ситуаціях [Електронний ресурс] / М.Зубарєва. - Режим доступу : http://journlib.univ.kiev.ua/index.php?act=article\&article=2350

5. Лалл, Дж. Мас-медіа, комунікація, культура. Глобальний підхід / Джеймс Лалл. К., 2002. 264 c.

6. Лось Й. Публіцистика й тенденції розвитку світу (львівська школа журналістики) : навч . пос. для вузів / Й. Лось. Львів : Вид-во Львів. ун-ту ім. І. Франка, 2007. 373 с.

7. Михайлин I. Основи журналістики: підручник / I. Михайлин. К. : Центр учбової літератури, 2011. $496 \mathrm{c}$.

8. Почепцов Г. Информация и дезинформация / Г. Почепцов. К. : Эльга Ника-Центр, 2001. $256 \mathrm{c}$

9. Різун, В. Природа й структура комунікативного процесу [Електронний ресурс] / В. Різун. - Режим доступу : http://journlib.univ. kiev.ua/index. php?act=article\&arti$\mathrm{cle}=1005$ 
10. Чапала О. Засоби масової інформації в протидії кризовим явищам у суспільному житті / О. Чапала // Наше право. Ч. 7. 2014. С. 84-87.

11. Вайнберг О. Криза і ЗМІ: як політичний клінч в Україні гальмує конкретні реформи [Електронний ресурс] / О.Вайнберг. - Режим доступу : https://voxukraine.org/uk/ how-the-ukrainian-crisis-plays-out-in-the-public-media-sector-ua/

12. Овсяник В. Кризові комунікації в умовах надзвичайних ситуацій [Електронний ресурс] / В. Овсяник // Вісник НАДУ при Президентові України. Сер. «Державне управління». 2018. Ч. 2. С. 105-111. - Режим доступу : http://visnyk.academy.gov.ua/ pages/dop/79/files/0faf032f-49a3-4e41-abde-1a8f185d8ea4.pdf

13. Практичний посібник для працівників комунікаційних структур в органах влади [Електронний ресурс] : Частина 2. - Режим доступу : https:/imi.org.ua/advices/ praktichniy-posibnik-dlya-pratsivnikiv-komunikatsiynih-struktur-v-organah-vladichastina-2/

14. Як висвітлювати конфліктно вразливі групи населення [Електронний ресурс]. Режим доступу : https://imi.org.ua/advices/yak-visvitlyuvati-konfliktno-vrazlivi-grupinaselennya-infografika/

15. Журналістика в умовах конфлікту: передовий досвід та рекомендації: Посібник рекомендацій для працівників ЗМІ. К.: «Компанія ВАITЕ», 2016. 118 с.

16. Почепцов Г. Світ базується на інформації та будується нею [Електронний ресурс] / Г. Почепцов. 3 лют. 2019. - Режим доступу : https:/dt.ua/internal/u-gluhih-lisahsocmedia-301473 html

17. Viner K. A mission for journalism in a time of crisis [Electronic resource] / K. Viner. Available from : https://www.theguardian.com/news/2017/nov/16/a-mission-forjournalism-in-a-time-of-crisis

18. Висвітлення конфлікту на Сході в українських медіа. Спеціальний звіт. К. : ГО «Детектор медіа». $19 \mathrm{c}$.

19. Медіа про конфлікти [Електронний ресурс]. - Режим доступу : http://journalism. ucu.edu.ua/navchannya/zhurnalistika/media-pro-konflikti/ 


\title{
TOLERANCE OF MASS MEDIA IN CHRISIS
}

\author{
Tetiana Khomenko \\ Ivan Franko National University of Lviv, \\ Generala Chuprynky Str., 49, 79044, Lviv, Ukraine \\ e-mail: homenko.tet@gmail.com \\ https://orcid.org/0000-0003-2917-3469
}

The article deals with problems the journalists face while enlightening difficult conflicts and critical periods in the life of any man, country, or society in general. The author takes into consideration the fact that chrisis can be seen as a kind of aggravation of the conflict. This is why journalists, being mediators of social polylogue, are supposed to provide the society with valid information in advance, as we may say, in order to avoid conflicts, or in order to resolve it at various levels (political, economical, sociocultural, private etc) of social life by the means of qualitative analysis and estimation of the conflict. During our life we face with various chrisises at our personal level. While trying to establish dialogues with othres, global chrisises sometimes appear to be unavoidable. This is when a so-called mediator is required in order to deal properly with critical situation and to find proper solution to it. In the context of current topic Mass media is considered to play a role of such mediators. In the mean time, every reader has free access to any information, on the one hand, and on the other he risks of getting lost and confused not only in the thematical variety, but in pluralistic flow of various kinds of verities, semi-verities, and direct manipulations. In such circumstances deontological problem of freedom and free choice concerning formation of the field of information, its analysis, as well as acquaintance of the readers is very important. The tolerant choice of the journalist is supposed to be at the side of thruth at all times, and in addition to this, the choice of professional journalis should rely on the notion of common good and be deprived of prejudiced presentation of information. Definitely, in this case established codexes for journalists would be of utmost importance. Unfortunately, this type of work reglamentation has not acquired popularity. But today the journalists themselves, relying on their personal experience, provide their colleagues with such recommendations, namely at mediaforums.

Key words: media, dialogue, chrisis, conflict, journalistic ethics. 